\title{
A Comparaison of Beekeeping Sectors between Slovakia and Romania
}

\author{
Peter ŠEDÍK ${ }^{1}$, Cristina Bianca POCOL ${ }^{2 *}$ and Elena HORSKÁ ${ }^{1}$ \\ ${ }^{1}$ Department of Marketing and Trade. Slovak University of Agriculture, Trieda Andreja Hlinku 609/2, \\ 94976 Nitra-Chrenová, Slovakia \\ ${ }^{2}$ Department of Economics. University of Agricultural Sciences and Veterinary Medicine, 3-5 Manastur \\ St., Cluj Napoca, Romania \\ *Corresponding author, e-mail: cristina.pocol@usamvcluj.ro
}

Bulletin UASVM Horticulture 74(2)/ 2017

Print ISSN 1843-5254, Electronic ISSN 1843-5394

DOI:10.15835/buasvmcn-hort: 0021

\begin{abstract}
Beekeeping sector plays an essential role in agriculture for two main reasons: the process of pollination and the production of honey and other apicultural products. The aim of the paper was to analyse and compare beekeeping sectors between Slovakia and Romania in terms of honey production, market competitiveness and EU funding budget allocation. The secondary data used in the analysis were provided by European Commission reports, the Romanian Institute of Statistics, Slovak statistics, Central Register of Hives in Slovakia, Faostat and Trademap. The competitiveness in honey market was calculated using RCA indices and the Michaely index. Results show that the number of hives as well as honey production increased, while market competitiveness decreased. In conclusion, national beekeeping programmes provide financial support for beekeepers and foster the whole sector, therefore the European Union should continue implementing these programmes to stabilize this sector and increase production capacities in both countries.
\end{abstract}

Keywords: Beekeeping sector, RCA indices, Romania, Slovakia

\section{INTRODUCTION}

Beekeeping is defined as an agricultural sector, which ensures sustainability of ecosystems and rural development involving also the production of honey and other bee products (Levický and Gurčík, 2014). The main indicators for the beekeeping sector are the number of beehives, the proportion of professional beekeepers and honey yields (Chlebo, 2017). Furthermore, beekeeping sector plays an essential role in agriculture because of the pollination process and, in addition, ensures the production of honey and other apicultural products. Worldwide, Apis mellifera is the crucial pollinator for monoculture (Klein et al., 2007) as honeybee can reach relatively long distance and possesses effective foraging behaviour (Künast et al., 2011). Pollination depends on the population of bees and any decrease of the population in the future may cause both ecological and economic problems in terms of ecosystems sustainability and food security (Opera Research, 2010). A significant reduce of the pollinators population can create a "pollination crisis" at a global level (Jacques et al., 2016).

After a significant loss of the bee population in Europe, the European Union realized that this sector is confronted with an urgent crisis and decided to start the implementation of beekeeping programmes, which included several measures on beekeeping in order to foster honey production and improve bee products marketing strategies. These measures involve disease prevention and hive restocking. The primary support came from the Council Regulation (EC) no. 1221/1997, which describes all necessary steps and rules for providing $50 \%$ of co-financing from the EU. Each 
member state had to create a national apiculture programme and plan budget allocation (Food and Agriculture Organization, 2011). The remaining $50 \%$ of funding is covered by the national budget of each member state (Pocol, 2011). As for the national beekeeping programme, the budget is allocated for these measures: varroasis control, technical assistance, rationalization of transhumance, hive restocking, applied research, honey analysis (European Commission, 2013). For 2017-2019, the European Union decided to extend these measures and include analyses of apiculture products and product quality (European Commission, 2017). Nowadays, product quality is more important than ever before (Nagyová et al., 2014).

The national beekeeping programmes ensure competitiveness of the sector by increasing and restocking beehives, increasing the number professional beekeepers, developing consultancy service for beekeepers, providing modern equipment and technologies, enhancing honey quality, productivity and monitoring honey market (European Commission, 2016).

The aim of this paper is to analyse and compare beekeeping sectors between Slovakia and Romania in terms of sector structure, honey production, competitiveness in honey market, the EU funding and budget allocation from national beekeeping programmes.

\section{MATERIALS AND METHODS}

For analysing the beekeeping sectors, was used secondary data provided by European Commission reports, the National Institute of Statistics in Romania, the Statistical Office of the Slovak Republic, the Central Register of Hives in Slovakia, FAOSTAT and Trademap. The assessment of competitiveness in honey market was calculated through RCA indices and the Michaely index.

The procedure for indices calculation

Revealed comparative advantage index RCA (1):

$R C A=\ln [(x: m) /(X: M)]$

Where:

$\mathrm{x}$ - export of a commodity,

m - import of a commodity,

$\mathrm{X}$ - total country's export,

$\mathrm{M}$ - total country's import.
Result of quantification:

RCA $>0$ - comparative advantage,

RCA $<0$ - comparative disadvantage.

(Levický and Lajdová, 2011)

Index of Competitiveness Growth RCA 1 (2):

$R C A 1=[(X i j: X i) /(X j: X)]$

Where:

Xij - export of country "i" in commodity group "j"

$\mathrm{Xi}$ - total export of country " $\mathrm{i}$ "

$\mathrm{Xj}$ - world's export in commodity group " $\mathrm{j}$ "

$\mathrm{X}$ - total world's export

Result of quantification:

RCA $1>1$ - revealed comparative advantage,

RCA $1<1$ - comparative disadvantage,

RCA1 = 1 - neutral competitiveness, do not quantify comparative advantage or disadvantage

(Aiginger and Landesmann, 2002)

Index of net business performance RCA 2 (NEI) (3):

$R C A 2=[(X i j-M i j) /(X i j+M i j)]$

Where:

Xij - export of country " $\mathrm{i}$ " in commodity group " $\mathrm{j}$ ",

Mij - import of country "i" in commodity group " $j$ ".

Result of quantification:

RCA II $(0,1>-$ comparative advantage (reduced import)

RCA II <-1,0) - comparative disadvantage (reduced export)

RCA II = 0 - export $=$ import $($ Balassa, 1965, p. 90-124)

\section{Michaely index (4):}

$M i=X i j /\left(\sum i X i j\right)+M i j /\left(\sum i M i j\right)$

Where:

Xij - the export of commodity group "i" of country " $\mathrm{j}$ "

Mij - the import of commodity group " $\mathrm{i}$ " of country " $\mathrm{j}$ "

$\sum \mathrm{iXij}$ - total national export

$\sum \mathrm{iMij}$ - total national import 
Tab. 1. Structure of beekeeping sector in Slovakia and Romania in 2015

\begin{tabular}{ccc}
\hline & Slovakia & Romania \\
\hline Number of beekeepers & 17171 & 22930 \\
\hline Number of hives & 278286 & 1392846 \\
\hline Number of beekeepers managing more than 150 hives & 56 & 1545 \\
\hline $\begin{array}{c}\text { Total number of beehives managed by beekeepers with } \\
\text { more than 150 beehives }\end{array}$ & 11457 & 299243 \\
\hline $\begin{array}{c}\text { Number of beekeepers organised in } \\
\text { beekeepers'associations }\end{array}$ & 16607 & 22930 \\
\hline
\end{tabular}

Source: European Commission, 2016

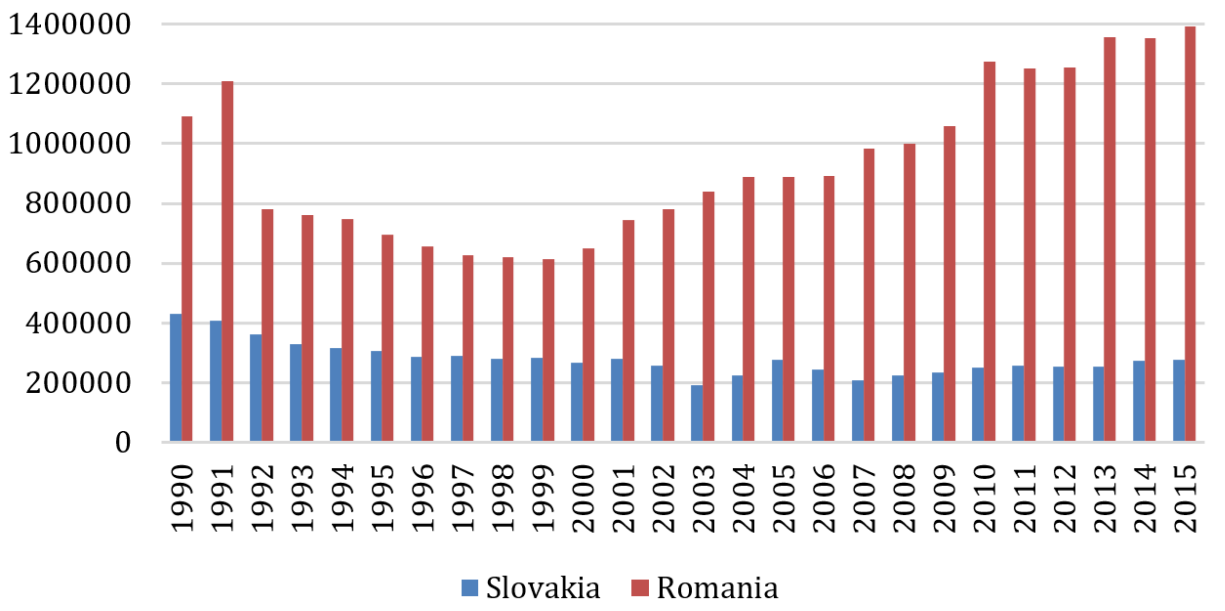

Fig. 1. Number of hives

Source: Slovak Central Register of Hives, Romanian Institute of Statistics

Result of quantification:

$0<\mathrm{Mi}<1-$. certain degree of specialization of a country, especially the commodity group

$-1<\mathrm{Mi}<0-$. insufficient degree of specialization of a country, especially the commodity group (Michaely, 1962)

\section{RESULTS AND DISCUSSION}

The beekeeping sector's structure is primary characterized by the number of beehives, beekeepers and professional beekeepers (beekeepers with more than 150 hives). As shown in Table 1, in 2015, Slovakia had 17171 beekeepers taking care of 278286 hives. Only 56 of them were professional beekeepers, counting for a number of 11457 hives. More than $90 \%$ of all beekeepers are organized in associations; mainly, in the Slovak Association of Beekeepers. The structure of this sector in Romania is slightly different. In 2015, the total number of beekeepers was 22930 with 1392846 hives. Approximately 1545 are professional beekeepers with 299243 hives. All beekeepers are organized.
Another important aspect in evaluating the beekeeping sector is the development of bee population in time. According to figure 1, the number of beehives in Slovakia had been decreasing since 1990 till 2004 when a slight recovery can be observed. However, a gradual increase has been observed after 2007 till nowadays. The situation in Romania is quite similar, where a sharp decrease had been observed in the period 1991 - 1999. The number of bees started to increase since 2000. Nevertheless, the significant increase has been recorded since 2007 till nowadays. The increasing tendency in number of hives in both countries has been significantly influenced by EU subsidies through beekeeping programmes implementations, including restocking hives and supporting new beekeepers as well as through measures financed by the National Rural Development Programme.

The number of hives and beekeepers relates to honey production. Figure 2 illustrates honey production in both countries for 2007 - 2015. 


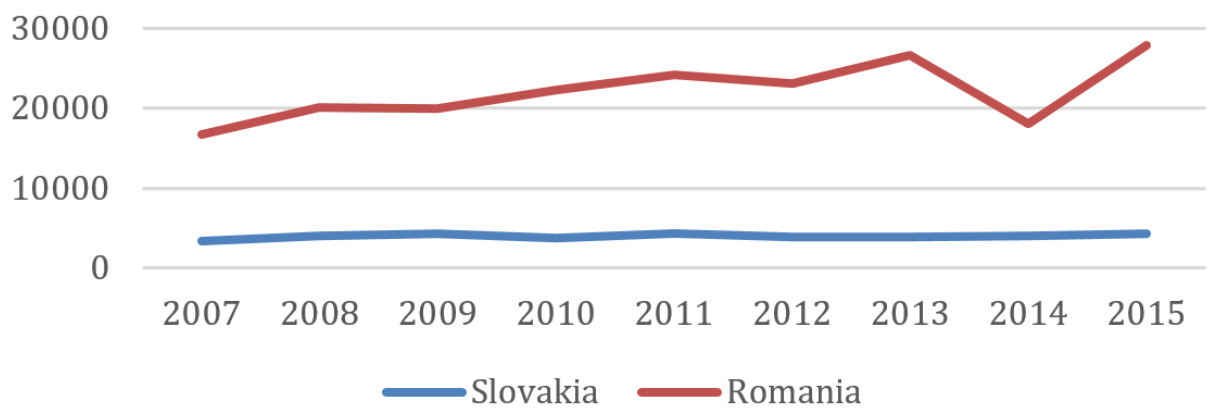

Fig. 2. Total honey production

Source: Faostat, Slovak Central Register of Hives and Romanian Institute of Statistics

Tab. 2. Changes in honey production during 2013-2015 in Slovakia

\begin{tabular}{cccc}
\hline \multirow{2}{*}{ Region } & Total production in kg, Total production in kg, & \multirow{2}{*}{$\Delta \%$} \\
& 2013 & 2015 & \multirow{2}{*}{$+12.96 \%$} \\
\hline Bratislava & 150797 & 170334 & $+9.48 \%$ \\
\hline Western Slovakia & 1552386 & 1699542 & $+16.00 \%$ \\
\hline Central Slovakia & 1085209 & 1258802 & $+7.00 \%$ \\
\hline Eastern Slovakia & 1091057 & 1167419 & $+10.74 \%$ \\
\hline Total & 3879449 & 4296098 &
\end{tabular}

Tab. 3. Changes in honey production during 2013-2015 in Romania

\begin{tabular}{cccc}
\hline Region & $\begin{array}{c}\text { Total production in } \\
\text { kg, } 2013\end{array}$ & $\begin{array}{c}\text { Total production in } \\
\text { kg, 2015 }\end{array}$ & $\Delta \%$ \\
\hline North - West & 3117000 & 3568000 & $+14.47 \%$ \\
\hline Center & 3958000 & 4269000 & $+7.86 \%$ \\
\hline North - East & 3433000 & 4081000 & $+18.88 \%$ \\
\hline South - East & 3130000 & 3271000 & $+4.50 \%$ \\
\hline South - Muntenia & 4152000 & 4058000 & $-2.26 \%$ \\
\hline Bucharest - Ilfov & 379000 & 277000 & $-26.91 \%$ \\
\hline Southwest Oltenia & 4491000 & 4657000 & $+3.70 \%$ \\
\hline West & 4018000 & 3712000 & $-7.62 \%$ \\
\hline Total & 26678000 & 27893000 & $+4.55 \%$ \\
\hline Source: Nationalnstitute of Statistics
\end{tabular}

Slovak beekeeping industry experiences a stable production with minor fluctuation from 3304 tons to 4326 tons, while in Romania honey production has been increasing continuously since 2007. However, a sharp decline was recorded in 2014 followed by a spectacular increase. One of the possible reasons for the massive decrease in 2014 could be the bad weather conditions or high bee mortality during winter.

For an even more insightful study, the next step was to analyse the percentage changes in honey production, by regions, between 2013 and 2015. Data show (see Tab. 2) that the total Slovakian honey production increased by $10.74 \%$. The major increase was obtained in these regions: Central Slovakia $(+16.00 \%)$ and Bratislava $(+12.96 \%)$. The lowest increase was recorded in Eastern Slovakia (+7.00\%).

A similar situation is observed in Romania (see Table 3), where the total honey production had increased by $4.55 \%$ from 2013 to 2015 . The highest increase was reached in North-East $(+18.88 \%)$ and North-West $(+14.47 \%)$ regions while lowest decrease was obtained in Bucharest 
Tab. 4. Budget allocation for 2014-2016

\begin{tabular}{ccc}
\hline Period & Slovakia & Romania \\
\hline $2013 / 2014$ & $1098966 €$ & $6683690 €$ \\
\hline $2014 / 2015$ & $1099170 €$ & $6684930 €$ \\
\hline $2015 / 2016$ & $1097820 €$ & $6676720 €$ \\
\hline Total & $3295956 €$ & $20045340 €$ \\
\hline Source: European Commission, 2017 & &
\end{tabular}

Tab. 5. Future budget allocation in Slovakia

\begin{tabular}{cccc}
\hline Measures/Years & $2016 / 2017$ & $2017 / 2018$ & $2018 / 2019$ \\
\hline Technical assistance & $890000 €$ & $890000 €$ & $890000 €$ \\
\hline Combating beehive invaders and diseases & $700000 €$ & $700000 €$ & $700000 €$ \\
\hline Rationalization of transhumance & $100000 €$ & $100000 €$ & $100000 €$ \\
\hline Analysis of apicultural products & $70000 €$ & $70000 €$ & $70000 €$ \\
\hline Restocking of hives & $200000 €$ & $200000 €$ & $200000 €$ \\
\hline Applied research programmes & $40000 €$ & $40000 €$ & $40000 €$ \\
\hline Market monitoring & $5000 €$ & $5000 €$ & $5000 €$ \\
\hline Enhancement of product quality & $5000 €$ & $5000 €$ & $5000 €$ \\
\hline Total & $1120000 €$ & $1120000 €$ & $1120000 €$ \\
\hline Source: European Commission 2016 & &
\end{tabular}

- Ilfov (-26.91\%), West (-7.62\%) and South Muntenia (-2.26\%) regions.

Honey production significantly depends on the number of beehives, rationalization of transhumance and modernization of technologies in beekeeping. In both countries, the number of hives increased, impacting the overall honey production, which increased as well. In Slovakia, many new beekeepers appeared due to subsidies provided through national beekeeping programmes. According to table 4, EU allocated in 2015/2016 the sum of $1097820 €$. A significant share was allocated to technical assistance, varroasis control, rationalization of transhumance and hive restocking. All these measures can influence bees' productivity. For example, Slovak beekeepers have moved their hives from one region to another to prolong the foraging period in order to increase their average production. For 20142016, both countries have been approved their national apiculture programmes. EU approved $3295956 €$ for Slovakia and $20045340 €$ for Romania (Tab. 4). The amount of approved fund depends on the number of beehives in country, therefore Romania got significantly higher funds than Slovakia.

Between 2017-2019, Slovakia is going to allocate approximately $1120000 €$ from the national beekeeping program. Most of these funds will be spent on technical assistance (890 $000 €)$ and measures to combat beehive invaders and diseases (700 $000 €$ ) as these issues still represent a major problem for beekeepers. Moreover, restocking of hives (200 $000 €$ ) and rationalization of transhumance (100000 €) is going to have a significant share in the budget allocation structure (Tab. 5).

According to table 6, Romania is planning to allocate around 7 million $€$. In comparison to Slovakia, Romania's budget is going to cover only a few measures. The major amount will be spent on restocking hives, followed by rationalization of transhumance and combating beehive invaders and disease. A smaller amount is going to be allocated to technical assistance and analysis of apicultural products. The measures such as applied research, market monitoring and enhancement of product quality will not be funded at all.

The last aspect in the evaluation of both beekeeping sectors is competitiveness on honey market. For this reason, several indices had been applied. In the case of measuring the degree of specialization in the honey industry, the Michaely index was applied. Slovakia obtained a certain degree of specialization on the market during 20032009 (see Figure 3). The range of calculated values 
Tab. 6. Future budget allocation in Romania

\begin{tabular}{cccc}
\hline Measures/Years & $2016 / 2017$ & $2017 / 2018$ & $2018 / 2019$ \\
\hline Technical assistance & $435000 €$ & $463500 €$ & $465000 €$ \\
\hline Combating beehive invaders and diseases & $1180371 €$ & $1196949.60 €$ & $1217948.72 €$ \\
\hline Rationalization of transhumance & $2042440.32 €$ & $2093280.28 €$ & $2137488.95 €$ \\
\hline Analysis of apicultural products & $320000 €$ & $0.00 €$ & $0.00 €$ \\
\hline Restocking of hives & $3526746.24 €$ & $3746684.35 €$ & $3757736.52 €$ \\
\hline Applied research programmes & $0.00 €$ & $0.00 €$ & $0.00 €$ \\
\hline Market monitoring & $0.00 €$ & $0.00 €$ & $0.00 €$ \\
\hline Enhancement of product quality & $0.00 €$ & $0.00 €$ & $0.00 €$ \\
\hline Total & $7504557.56 €$ & $7036914.23 €$ & $7578174.19 €$ \\
\hline Source: European Commission 2016 & & &
\end{tabular}

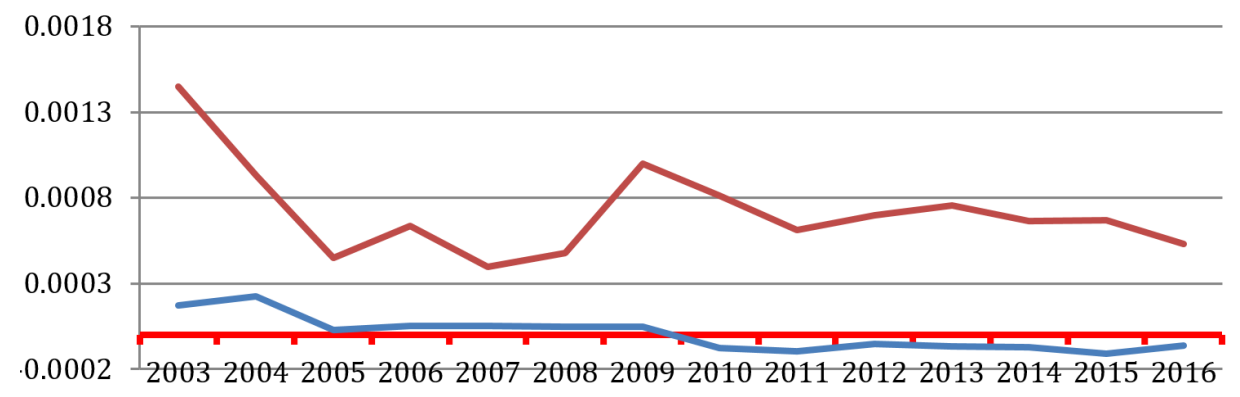

-Slovakia - Romania

Fig. 3. Michaely index

Source: Trademap, 2017

Tab. 7. RCA indices

\begin{tabular}{|c|c|c|c|c|c|c|c|c|c|c|c|c|c|c|}
\hline \multicolumn{15}{|c|}{ Revealed Comparative Advantage (RCA) } \\
\hline & 2003 & 2004 & 2005 & 2006 & 2007 & 2008 & 2009 & 2010 & 2011 & 2012 & 2013 & 2014 & 2015 & 2016 \\
\hline Slovakia & 1.19 & 1.68 & 0.48 & 0.74 & 0.21 & 0.30 & 0.78 & -1.34 & -1.16 & -0.89 & -0.60 & -0.87 & -1.54 & -1.83 \\
\hline Romania & 4.15 & 5.25 & 6.04 & 5.32 & 3.60 & 3.04 & 3.59 & 3.09 & 2.62 & 2.35 & 2.40 & 1.98 & 2.15 & 1.69 \\
\hline \multicolumn{15}{|c|}{ Index of Competitiveness Growth (RCA 1) } \\
\hline & 2003 & 2004 & 2005 & 2006 & 2007 & 2008 & 2009 & 2010 & 2011 & 2012 & 2013 & 2014 & 2015 & 2016 \\
\hline Slovakia & 1.89 & 2.92 & 1.15 & 1.50 & 4.07 & 2.21 & 0.89 & 0.27 & 0.46 & 0.38 & 0.75 & 0.42 & 0.22 & 0.08 \\
\hline Romania & 11.47 & 9.96 & 6.60 & 9.24 & 6.19 & 6.21 & 10.14 & 8.56 & 6.94 & 8.03 & 7.56 & 6.27 & 5.52 & 4.61 \\
\hline \multicolumn{15}{|c|}{ Index of Net Business Performance (RCA 2) } \\
\hline & 2003 & 2004 & 2005 & 2006 & 2007 & 2008 & 2009 & 2010 & 2011 & 2012 & 2013 & 2014 & 2015 & 2016 \\
\hline Slovakia & 0.52 & 0.67 & 0.20 & 0.32 & 0.10 & 0.13 & 0.38 & -0.59 & -0.52 & -0.40 & -0.27 & -0.38 & -0.64 & -0.72 \\
\hline om & 0.96 & 0.99 & 0.99 & 0.98 & 0.91 & 0.85 & 0.93 & 0.89 & 0.84 & 0.79 & 0.82 & 0.73 & 0.76 & 0.64 \\
\hline
\end{tabular}

was from 0.0002243 to 0.0000299 . However, since then, it reached an insufficient degree of specialization. The range was from -0.0000520 to -0.000111 in comparison with Romania that achieved, for all years analysed, a certain degree of specialization with data ranging from 0.00144 to 0.00039. Nevertheless, specialization has a decreasing trend as most products in Romania in terms of specialization (Ignjatijević et al., 2015).

The next RCA indices shows competitiveness in terms of comparative advantage and according to table 7 , Slovakia obtained the comparative 
advantage between 2003-2008 in RCA and RCA 1 and 2003-2009 in RCA, which was influenced by suitable climate conditions and rich bee pasture (Levický and Lajdová, 2011). However, the situation has changed and after 2008 and 2009, Slovakia has lost this advantage until today. It can be explained by an overall decrease in competitiveness of the whole food industry in Slovakia (Qineti et al., 2009) as well as due to increasing consumption of honey which cause higher demand and increase of imported honey as food market is influenced by the new trends connected with healthy lifestyle (Kubicová and Kádeková, 2016). The situation in Romania is different as, for the whole period and for all indices, Romania achieved comparative advantage in honey trade as it is net exporter of honey with good recognition worldwide (Pocol et al., 2017). The maximum value was obtained in 2003 (11.47) and the lowest value in 2014 (1.98).

\section{CONCLUSION}

The paper analysed and compared beekeeping sectors in Slovakia and Romania and EU funding through national beekeeping programmes. Regarding the structure of beekeeping sectors, Romania has 5000 more beekeepers than Slovakia and 5 times more hives. The number of professional beekeepers is higher in Romania. Since 2007, both countries have an increasing trend in number of hives. The Slovakian production of honey is stable, while the Romanian production has been continuously increasing since 2007. Both countries have positive percentage change in overall honey production in the period of 20132015. However, three Romanian regions: South Muntenia, West and Southwest Oltenia obtained negative changes. In terms of EU funding, both countries are using this opportunity through national apiculture programmes. While Slovakia is going to allocate funds among all measures, Romania is going to allocate funds only for restocking hives, rationalisation of transhumance, combating beehive invaders and disease, technical assistance and analysis of apicultural products. As for market competitiveness, Romania obtained for all indices a comparative advantage, despite registering a decreasing tendency. Slovakia obtained a comparative advantage between 2003-2009, losing this advantage after 2009. This situation occurred due to the increasing honey consumption, which lead to a growth of honey volumes imported from other countries.

\section{RECOMMENDATIONS}

The implementation of national beekeeping programmes provides financial support for beekeepers and foster the whole sector. For all these reasons, the European Union should continue to support beekeepers to stabilize this sector and increase production capacities in both countries.

Funding: This research did not receive any specific grant from funding agencies in the public, commercial, or non-profit sectors.

\section{REFERENCES}

1. Aiginger K, Landesmann M (2002). Competitive Economic Performance: The European View [WIFO Working Papers 179/2002]. Wienna: Austrian Institute of Economic Research.

2. Balassa B (1965). Trade Liberalisation and Revealed Comparative Advantage. Manchester: Manchester School of Economics and Social Studies.

3. Chlebo R (2017). Podmienky rozvoja včelárstva na Slovensku. Nitra: Slovenská pol'nohospodárska univerzita.

4. European Commission (2013). Regulation (EU) no 1308/2013 of the European Parliament and of the Council of 17 December 2013 establishing a common organisation of the markets in agricultural products and repealing Council Regulations (EEC) No 922/72, (EEC) No 234/79, (EC) No 1037/2001 and (EC) No 1234/2007. Official Journal of the European Union. http://eur-lex.europa.eu/ legal-content/EN/TXT/PDF/?uri=CELEX:32013R1308\&f rom=en Accessed 17.05.11.

5. European Commission (2016). Agriculture and Rural Development ISAMM CM. https://ec.europa.eu/ agriculture/sites/agriculture/files/honey/programmes/ national-apiculture/nap-sk_sk.pdf Accessed 17.05.11.

6. European Commission. (2017). National Apiculture Programmes. https://ec.europa.eu/ agriculture/honey/ programmes_en Accessed 17.05.11.

7. Food and Agriculture Organization (2011). Honey evaluation of the CAP measures related to apiculture agriculture and rural development DG - Final Report. https://ec.europa.eu/agriculture/sites/agriculture/ files/evaluation/market-and-income-reports/2013/ apiculture/fulltext_en.pdf Accessed 17.05.11.

8. Ignjatijević S, Milojević I, Cvijanović G, Jandrić M (2015). Balance of comparative advantages in processed food sector of the Danube countries. Sustainability, 7(6): 6976-6993. Doi: 10.3390/su7066976

9. Jacques A, Laurent M, EPILOBEE Consortium, RibièreChabert M, Saussac M, Bougeard S (2016). A panEuropean epidemiological study reveals honey bee colony survival depends on beekeeper education and disease 
control PLoS ONE 12(3). https://doi.org/10.1371/ journal.pone.0172591.

10. Klein AM, Vaissière BE, Cane JH, Dewenter IS, Cunningham SA, Kremen C, Tscharntke T (2007). Importance of pollinators in changing landscapes for world crops. Proc. Biol. Sci, 274: 303-313. Doi:10.1098/rspb.2006.3721.

11. Kubicová L', Kádeková Z (2016). Development and level of consumption of chosen foods in Slovakia and Austria. The agri-food value chain: challenges for natural resources management and society. [online] Nitra: Slovak University of Agriculture, (pp. 777-782). Available at: http://dx.doi. org/10.15414/isd2016.s10.0. Accessed 17.06.01.

12. Künast Ch, Riffel M, Whitmore G (2011). Pollinators and Agriculture. http://www.phytofar.be/Files/Upload/ Docs/04_Pollinators_Agriculture.pdf. Accessed 17.06.09.

13. Levický M, Gurčík L' (2014). Ekonomické a manažérske faktory chovu včelstiev na Slovensku. Nitra: Slovenská pol'nohospodárska univerzita.

14. Levický M, Lajdová Z (2011). Revealed comparative advantage and competitiveness in honey trade: the case of Slovakia. Zborník príspevkov z medzinárodneh vedeckej konferencie, October 2011, p.229. ISBN 978-80-5520716-2.
15. Michaely M, (1962). Concentration in International Trade, Contributions to Economic Analysis. Amsterdam: NorthHoland Publishing Company.

16. Nagyová L', Košičiarová I, Kádeková Z (2014). Značka kvality: garancia kvality potravín na národnej úrovni krajín EU. (1st ed.). Nitra : Slovenská polnohospodárska univerzita.

17. Opera Research (2010). Bee health in Europe- An overview. Retrieved April 10, 2017 from http://operaresearch.eu/ files/repository/20121210154701_BeeHealthinEuropeAnoverview.pdf Accessed 17.06.20.

18. Pocol CB, Ignjatijević S, Cavicchioli D (2017). Production and Trade of Honey in Selected European Countries: Serbia, Romania and Italy, Honey Analysis, Prof. Vagner Arnaut De Toledo (Ed.), InTech, Doi: 10.5772/66590.

19. Pocol CB (2011). Sustainable policies for the development of beekeeping in Romania. Problems of World Agriculture/ Problemy Rolnictwa Światowego, 11(26): 107-114.

20. Qinet A, Rajcaniova M, Matejkova E (2009). The competitiveness and comparative advantage of the Slovak and the EU agri-food trade with Russia and Ukraine. Agric. Econ. Zemed. Ekon. 55: 375-383. 